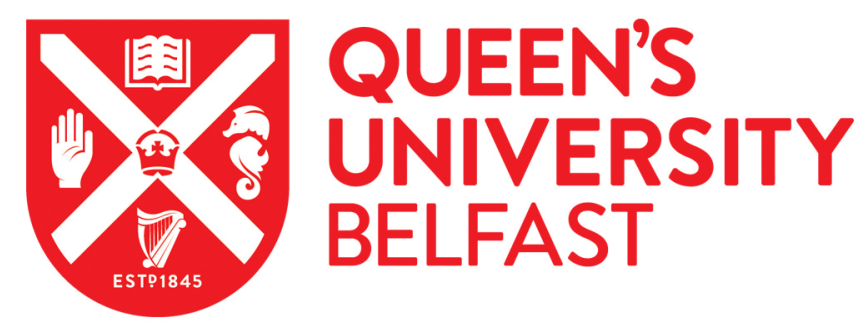

\title{
The endocrine disrupting potential of monosodium glutamate (MSG) on secretion of the glucagon-like-peptide-1 (GLP-1) gut hormone and GLP-1 receptor interaction
}

Shannon, M., Green, B., Willars, G., Wilson, J., Matthews, N., Lamb, J., Gillespie, A., \& Connolly, L. (2017). The endocrine disrupting potential of monosodium glutamate (MSG) on secretion of the glucagon-like-peptide-1 (GLP-1) gut hormone and GLP-1 receptor interaction. Toxicology Letters, 265, 97-105.

https://doi.org/10.1016/j.toxlet.2016.11.015

Published in:

Toxicology Letters

Document Version:

Peer reviewed version

Queen's University Belfast - Research Portal:

Link to publication record in Queen's University Belfast Research Portal

Publisher rights

(c) 2016 Elsevier Ltd. This manuscript version is made available under the CC-BY-NC-ND 4.0 license http://creativecommons.org/licenses/by$\mathrm{nc}-\mathrm{nd} / 4.0 /$ which permits distribution and reproduction for non-commercial purposes, provided the author and source are cited.

\section{General rights}

Copyright for the publications made accessible via the Queen's University Belfast Research Portal is retained by the author(s) and / or other copyright owners and it is a condition of accessing these publications that users recognise and abide by the legal requirements associated with these rights.

\section{Take down policy}

The Research Portal is Queen's institutional repository that provides access to Queen's research output. Every effort has been made to ensure that content in the Research Portal does not infringe any person's rights, or applicable UK laws. If you discover content in the

Research Portal that you believe breaches copyright or violates any law, please contact openaccess@qub.ac.uk. 
1 The endocrine disrupting potential of monosodium glutamate (MSG) on secretion of the glucagon-like peptide-1 (GLP-1) gut hormone and GLP-1 receptor interaction

Maeve Shannon ${ }^{1}$, Brian Green ${ }^{1}$, Gary Willars² ${ }^{2}$ Jodie Wilson $^{1}$, Natalie Matthews ${ }^{1}$, Joanna Lamb $^{1}$, Anna Gillespie ${ }^{1}$ and Lisa Connolly ${ }^{1}$

$5{ }^{1}$ Institute for Global Food Security, School of Biological Sciences, Queen's University, 6 Belfast, Northern Ireland, United Kingdom.

$7{ }^{2}$ Department of Molecular and Cell Biology, University of Leicester, Leicester, England,

8 United Kingdom

9 Corresponding author and person to whom reprint requests should be addressed:

10 Dr. Lisa Connolly

11 Institute for Global Food Security

12 Queen’s University Belfast

13 18-30 Malone Road Belfast, BT9 5BN

14 Phone: +44 (0)28 90976668

15

Email: l.connolly@qub.ac.uk

16

17

18

19

20 
Abstract

25

Monosodium glutamate (MSG) is a suspected obesogen with epidemiological evidence positively correlating consumption to increased body mass index and higher prevalence of metabolic syndrome.

ELISA and high content analysis (HCA) were employed to examine the disruptive effects of MSG on the secretion of enteroendocrine hormone glucagon-like peptide-1 (GLP-1) and GLP-1 receptor (GLP-1R), respectively. Following 3 h MSG exposure of the enteroendocrine pGIP/neo: STC-1 cell line model (500 $\mu \mathrm{g} / \mathrm{ml})$ significantly increased GLP-1 secretion (1.8 fold; $\mathrm{P}<0.001)$, however, $72 \mathrm{~h}$ exposure $(500 \mu \mathrm{g} / \mathrm{ml})$ caused a 1.8 fold decline $(P<0.05)$. Also,3 h MSG exposure $(0.5-500 \mu \mathrm{g} / \mathrm{ml})$ did not induce any cytotoxicity (including multiple pre-lethal markers) but $72 \mathrm{~h}$ exposure at 250-500 $\mu \mathrm{g} / \mathrm{ml}$, decreased cell number $(11.8-26.7 \%$; $P<0.05)$, increased nuclear area $(23.9-29.8 \% ; P<0.001)$ and decreased mitochondrial membrane potential (13-21.6\%; $P<0.05)$. At $500 \mu \mathrm{g} / \mathrm{ml}$, MSG increased mitochondrial mass by $16.3 \%(P<0.01)$. MSG did not agonise or antagonise internalization of the GLP-1R expressed recombinantly in U2OS cells, following GLP-1 stimulation. In conclusion, $72 \mathrm{~h}$ exposure of an enteroendocrine cell line at dietary levels of MSG, results in pre-lethal cytotoxicity and decline in GLP-1 secretion. These adverse events may play a role in the pathogenesis of obesity as outlined in the obesogen hypothesis by impairing GLP-1 secretion, related satiety responses and glucose-stimulated insulin release.

Key terms: Monosodium glutamate, in vitro bioassays, high content analysis, GLP-1, diabetes; obesity 
The incidence of obesity and metabolic diseases such as diabetes has risen dramatically over the past two decades. The United Kingdom (UK) is officially the most obese country in Europe with 1 in 5 adults overweight and 1 in 15 adults obese. It is predicted that the number of obese individuals will soar by a staggering $73 \%$ to 26 million people in the UK over the next twenty years. This is expected to fuel increases in cases of diabetes which in 2010 were estimated at 285 million worldwide with a predicted increase by $54 \%$ in 2030 due to population growth, ageing of populations and urbanization with associated lifestyle change (Shaw et al., 2010). Increased caloric intake and decreased physical activity are undoubtedly the major drivers of these increases but other factors have been highlighted (COT, 2013). Several lines of evidence, including several human epidemiological studies, suggest that certain chemicals in the diet or environment (referred to as 'obesogens') play a role in promoting obesity (Sharpe and Drake, 2013).

Monosodium glutamate (MSG) is a flavour enhancer used in many household prepared and processed foods worldwide which has recently been highlighted as a suspected dietary obesogen (Holtcamp, 2012). It is also believed that the effects of MSG are compounded further by its widespread availability in manufactured foods and the high frequency with which some individuals consume it (Mercola, 2009). A study investigating the effect of a lipid-containing meal with added MSG (2000 mg/meal) on glucose homeostasis, incretin secretion and gastric emptying in humans demonstrated GLP-1 plasma levels were significantly increased (Hosaka et al., 2012).. This demonstrates that exposure to MSG can have effects on the regulation of gut hormone secretion and consequently, glucose and weight homeostasis and highlights its potential to act as an endocrine disruptor.

The reported daily MSG intake of individuals varies greatly across the population. The reported UK average intake in 1991 was $580 \mathrm{mg} /$ day for the general population but 4.68 $\mathrm{g}$ /day for excessive consumers. In 2000, the average intake ranged from 300-1000 mg/day in industrialised countries (Husarova and Ostatnikova, 2013). However, more recent studies state that the average intake of MSG is around $0.4 \mathrm{~g} / \mathrm{day}$ in Europe and has been steadily increasing (Collision et al., 2009, He et al., 2011, Nakanishi et al., 2008). It is also important to consider Asian countries, where MSG consumption is much higher than other parts of the world. A study conducted in China found that the mean intake of MSG for the entire population was $3.1 \mathrm{~g} /$ day (Shi et al., 2014). Current legislation does not impose any limit on the amount of MSG that restaurants or the food industry can add to their products. Furthermore, food processors and manufacturers are not obligated to list the amount of MSG 
on their packaging. This anomaly makes it difficult to accurately monitor levels of MSG consumption and underestimations most likely occur.

A number of studies have investigated potential links between MSG, obesity and other metabolic disorders such as diabetes. In a longitudinal study, He et al. (2011) examined the association between MSG consumption and the incidence of overweight adults, reporting that a cumulative mean ( \pm standard deviation) MSG intake of $2200 \pm 1600 \mathrm{mg} /$ day is associated with an increase in body mass index (BMI) after adjustment for potential confounders. The extent of weight gain in MSG users compared with non-users was modest. However, there is still major public health interest in knowing whether weight gain is modulated by MSG intake. Further studies are necessary to investigate potential mechanisms where MSG could enhance the risk of obesity/diabetes (He et. al., 2011). A study conducted in Thailand reported a significantly higher prevalence of metabolic syndrome in the tertile with the highest MSG intake. Furthermore, for every 1000 mg more MSG intake per day, the risk of having metabolic syndrome or being overweight increased, regardless of the individual's total energy intake or physical activity level (Insawang et al. 2012).

Epidemiological studies and animal studies demonstrate an association between MSG consumption/MSG-injected models and weight gain (Clough et al., 1986; He et al., 2008; Hirata et al., 1997; Insawang et al., 2012; Iwase et al., 1998; Olney, 1969; Svidnicki et al., 2013). Miskowiak et al. (1993) found that rats administered with MSG displayed abnormal growth, obesity and reduced mass of the pituitary glands and testes, and also lower testosterone levels.

Most known or suspected obesogens are endocrine disruptors (EDs). Many are widespread with exposure suspected or confirmed as quite common (Holtcamp, 2012). Metabolic disorders may be influenced by endocrine disrupting interactions between consumed MSG and the hormones involved in controlling satiety responses and insulin release. Glucagon-like peptide 1 (GLP-1) is an intestinal gut hormone with important physiological roles including appetite control and is key in the regulation of post-prandial increases in insulin secretion, thereby regulating levels of glycaemia (Baggio and Drucker, 2007; Drucker, 2006). GLP-1 mediates its effects through the GLP-1 receptor (GLP-1R) which is a G-protein coupled receptor (GPCR) expressed in a wide range of human tissues including $\alpha, \beta$ and $\delta$-cells of the pancreatic islets, lung, kidney, heart, intestine, stomach, skin, vagal nerve and several regions of the central nervous system (CNS) including the hypothalamus and brainstem. GLP-1Rs 
have been shown to rapidly internalise following activation by GLP. A study by Kuna et al., 2013 demonstrated that GLP-1 receptor internalisation was induced by $0.1 \mu \mathrm{M}$ GLP-1 2 minutes to $1 \mathrm{~h}$. Internalised receptors are then either recycled back to the cell surface where they can again engage with ligands, or are targeted for post-endocytic degradation, which results in permanent signal termination from the receptor (Noerklit et al., 2014).

GLP-1 is well established to regulate bodyweight by stimulating feelings of satiety via GLP$1 \mathrm{R}$ in the brain (Baggio and Drucker, 2007; Drucker, 2006). In addition to the most well characterised effect, the amplification of glucose-stimulated insulin secretion, GLP-1 is now known to induce expansion of insulin-secreting $\beta$-cell mass. The mechanism by which GLP-1 is believed to enhance insulin secretion is through the regulation of ion channels (including ATP-sensitive $\mathrm{K}^{+}$channels, voltage-dependent $\mathrm{Ca}^{2+}$ channels, voltage-dependent $\mathrm{K}^{+}$ channels, and nonselective cation channels) and by the regulation of intracellular energy homeostasis and exocytosis (Macdonald et al., 2002). A number of clinical trials have been conducted in order to investigate the weight loss effect of GLP-1R agonist therapies in diabetic patients. A correlation between these therapies and weight loss has been established with the GLP-1R agonist liraglutide having a significant positive effect on weight loss (Buse et al., 2013).

Hosaka et al., (2012) investigated the effect of a lipid-containing meal with added MSG (2000 mg/meal) on glucose homeostasis, incretin secretion and gastric emptying in humans. GLP-1 plasma levels were significantly increased (although the mechanism for this was not determined). One possible mechanism could be through the interaction of the GLP-1R. It is well-established that sustained GLP-1R antagonism (with exendin (9-39)) impairs glucose tolerance, decreases insulin secretion and causes hyperglycaemia (D’Alessio et al., 1996; Edwards et al., 1999; Kolligs, Fehmann et al., 2002; Green et al., 2005; Scrocchi et al., 1996). As MSG is proposed to be an obesogen it seems logical to investigate whether it can disrupt the GLP-1/GLP-1R axis.

This is the first study assessing a potential obesogenic mechanism for MSG and the aims are to primarily investigate $3 \mathrm{~h}$ and $72 \mathrm{~h}$ exposure effects of MSG on GLP-1 secretion in vitro and also to investigate any potential mechanisms through 1) examining $3 \mathrm{~h}$ and $72 \mathrm{~h}$ toxicity of MSG on enteroendocrine (EE) cells (pGIP/neo: STC-1 cells, a sub-clone of the STC-1 cell line which secretes GLP-1) including measures of subtle pre-lethal cytotoxicity and 2) 
studying the endocrine disrupting potential of MSG on the GLP-1 receptor using a GLP-1R redistribution assay and high content analysis (HCA).

\section{Materials and methods}

\subsection{Chemicals and reagents}

Cell culture reagents and Hank's Balanced Salt Solution (HBSS) were supplied by Life Technologies (Paisley, UK). The reference standard GLP-1 (7-37) was obtained from Abcam (Cambridge, UK). MSG, thiazolyl blue tetrazolium bromide (MTT) and formalin were all supplied by Sigma-Aldrich (Poole, Dorset, UK). Hoechst nuclear stain and mitochondrial membrane potential dye were provided by Thermo Scientific (UK). GLP-1 ELISA kits were purchased from Millipore (Billerica, MA, USA). All other reagents were standard laboratory grade.

\subsection{Cell culture}

The U2OS-GLP1R-EGFP cell line (a U2OS cell line with stable expression of the human GLP-1R with a C-terminal EGFP tag) was obtained from Thermo Scientific (UK) and grown in $75 \mathrm{~cm}^{2}$ tissue culture flasks (Nunc, Roskilde, Denmark) at $37{ }^{\circ} \mathrm{C}$ with $5 \% \mathrm{CO}_{2}$ and $95 \%$ humidity. The cells were cultured routinely in Dulbecco's modified Eagle medium (DMEM) media with Glutamax, 10\% foetal bovine serum (FBS), 1\% penicillin and streptomycin (50 $\mathrm{U} / \mathrm{ml}$ ) and $50 \mathrm{mg} / \mathrm{ml} \mathrm{G} 418$. Cells were grown in plating media (DMEM with Glutamax, 1\% FBS, 1\% penicillin and streptomycin $(50 \mathrm{U} / \mathrm{ml})$ ) for $24 \mathrm{~h}$ prior to running the assay. Test compounds and standards were diluted in assay media (DMEM with Glutamax, 1\% penicillin and streptomycin $(50 \mathrm{U} / \mathrm{ml}))$. The assay has been validated with cells up to a passage of 30 (Thermo Scientific, UK).

pGIP/neo: STC-1 cells are an enteroendocrine (EE) cell model and its GLP-1 secretory ability has been extensively investigated (Gillespie et al., 2015; Jafri et al., 2016). These were a gift from Dr. B. Wice (Washington University of St. Louis) with permission from Dr. D. Hanahan (University of California, San Francisco, CA). Cells were cultured DMEM with Glutamax, 10\% FBS, 1\% penicillin and streptomycin (50 U/ml) and 50 mg/ml G418. Cells were passaged at 80-90\% confluence and used between passages 15-50. 
In addition to visual inspection of cells under the microscope to evaluate cell morphology and attachment, two cell viability assays were used to assess cytotoxic effects of MSG exposure.

The thiazolyl blue tetrazolium bromide (MTT) assay was used to monitor the cytotoxic effects of MSG test concentrations in the U2OS-GLP1R-EGFP cell line. Viable cells convert the soluble yellow MTT into insoluble purple formazan by the action of mitochondrial succinate dehydrogenase. For the U2OS-GLP1R-EGFP cells, clear flat-bottomed 96-well plates (Nunc, Roskilde, Denmark) were seeded with 6 x $10^{4}$ cells and the test compound was added after $24 \mathrm{~h}$ and incubated for a further $1 \mathrm{~h}$. The supernatant was discarded and $50 \mu \mathrm{l}$ of MTT solution/well (5mg/ml stock in phosphate buffered saline (PBS) diluted in 1:2.5 in assay media) was added and cells were incubated for a further $3 \mathrm{~h}$. Again, supernatant was removed and $200 \mu \mathrm{l}$ of DMSO was added to each well (to dissolve the formazan crystals) and incubated for a further $10 \mathrm{~min}$ with agitation at $37^{\circ} \mathrm{C}$. Optical density was measured using a Sunrise spectrophotometer at $570 \mathrm{~nm}$ with a reference filter at $630 \mathrm{~nm}$ (TECAN, Switzerland). Samples were tested in triplicate and in three independent exposures. Viability was calculated as a percentage absorbance of the sample when compared with the absorbance of the solvent control.

\subsubsection{Alamar Blue}

The viability of the pGIP/neo: STC-1 cells in the acute and chronic study was determined using the AlamarBlue ${ }^{\circledR}$. After removal of media for hormone analysis, $1 \mathrm{ml}$ of 1:10 (v:v) AlamarBlue ${ }^{\circledR}$ in cell culture medium was added to each well and incubated for $24 \mathrm{~h}$. A 100 $\mu \mathrm{l}$ volume was then removed from each well and added into clear flat-bottomed 96-well microtiter plates (BD Biosciences, Bedford, MA, US). Using a Sunrise spectrophotometer (TECAN, Switzerland) the absorbance was measured at $570 \mathrm{~nm}$ and $600 \mathrm{~nm}$. Viability was the solvent control (0.1\%, v: $\mathrm{dH}_{2} 0$ (deionised water) in media). 


\subsection{GLP-1R redistribution assay}

U2OS-GLP1R-EGFP cells were seeded (100 $\mu \mathrm{l}$ of 6 x 10 ${ }^{4}$ cells/well) in 96-well black plates with clear, flat bottoms. The cells were allowed to attach for $24 \mathrm{~h}$ before adding $100 \mu \mathrm{l}$ of the test sample (MSG) and the GLP-1 (7-37) standards at a final $\mathrm{dH}_{2} \mathrm{O}$ and dimethyl sulfoxide (DMSO) concentration of $0.2 \%$. To assess whether MSG had a disruptive (or antagonistic) effect on the interaction of GLP-1 with the GLP-1R, the potential of MSG to influence GLP1-mediated internalisation of the EGFP-tagged GLP-1R was assessed. Thus, the ability of $150 \mathrm{nM}$ GLP-1 to induce internalisation of the receptor was assessed in the absence and presence of MSG. Cells were incubated for $1 \mathrm{~h}$ in a $37^{\circ} \mathrm{C}, 5 \% \mathrm{CO}_{2}$, humidified incubator, before decanting buffer and fixation of the cells with $100 \mu \mathrm{l} /$ well of formalin (approximately $4 \%$ formaldehyde). Cells were incubated for a further $20 \mathrm{~min}$ at room temperature and then washed four times with $200 \mu$ PBS per well per wash followed by addition of $100 \mu \mathrm{l}$ of 1 $\mu \mathrm{M}$ Hoechst staining solution $(1 \mu \mathrm{l}: 10 \mathrm{ml}$ PBS $)$ to each well. After $30 \mathrm{~min}$, the plate was imaged on a Thermo Scientific Arrayscan HCS. The filters were set for the Hoechst dye (350/461 nm) and GFP/FITC (488/509 nm). The SpotDetectorV3 BioApplication was used for carrying out the reading step of the GLP-1R redistribution assay using the ObjectSpotAvgIntensity parameter and both data and corresponding images are generated (see Fig 1 for example of images). The assay was performed in triplicate for each experimental point and repeated in three independent exposures. The response of the cell line to the various compounds was measured and compared with the $\mathrm{dH}_{2} \mathrm{O}$ solvent control.

\subsection{HCA cytotoxicity assay}

The Cellomics ${ }^{\circledR}$ HCS reagent series multiparameter cytotoxicity assay was performed according to the manufacturer's instructions. pGIP/neo: STC-1 cells were seeded $6 \times 10^{4}$ in 96 well plates 24 hours prior to the assay. Briefly, mitochondrial membrane potential dye was prepared by adding $117 \mu \mathrm{l}$ of anhydrous DMSO to make a $1 \mathrm{mM}$ stock. Following incubation (3 h or $72 \mathrm{~h}$ ), $50 \mu \mathrm{l}$ of live cell stain was added to each well for $30 \mathrm{~min}$ at $37^{\circ} \mathrm{C}$ and protected from light. The live stain was removed and cells were then fixed with a $10 \%$ formalin solution for 20 min at room temperature, protected from light and washed with PBS. Hoechst 33342 dye at a final concentration of $1.6 \mu \mathrm{M}$ was added to each well and incubated for 10 min at room temperature and protected from light; after which cells were washed with PBS four times and evaluated on a CellInsight ${ }^{\mathrm{TM}}$ NXT High Content Screening (HCS) Platform 
240 (Thermo Fisher Scientific, UK). Hoechst stain was used to measure cell number and nuclear morphology including nuclear intensity and nuclear area while mitochondrial membrane potential dye was used to measure mitochondrial health, specifically mitochondrial membrane potential and mitochondrial mass. Data were captured for each plate using a $\times 10$ objective magnification in the selected excitation and emission wavelengths of Hoechst dye (Ex/Em 350/461 nm) and mitochondrial membrane potential dye (Ex/Em 554/576 nm). For each well, 25 field of view images were acquired to examine each parameter with each image containing approximately 6,000 cells.

\subsection{GLP-1 secretion studies}

\subsubsection{3 h exposure}

The pGIP/neo: STC-1 cells were seeded into 24 -well plates $\left(1 \times 10^{6}\right.$ per well) and cultured overnight at $37{ }^{\circ} \mathrm{C}$ in a humidified atmosphere of $5 \% \mathrm{CO}_{2}$. Medium was removed and cells were washed once with HBSS buffer and equilibrated for $1 \mathrm{~h}$ in $500 \mu \mathrm{l}$ HBSS buffer. Test compounds $\left(0.5,5,50,250,500 \mu \mathrm{g} / \mathrm{ml}\right.$ MSG in $\left.\mathrm{dH}_{2} \mathrm{O}\right)$ and $\mathrm{dH}_{2} \mathrm{O}$ solvent control diluted in HBSS buffer $(1000 \mu \mathrm{l})$ were added and allowed to incubate for a further $3 \mathrm{~h}$. Supernatant was removed and stored at $-20^{\circ} \mathrm{C}$ prior to hormone analysis.

\subsubsection{2 h exposure}

Initially cells were seeded into 96 well plates ( $5 \times 10^{4}$ per well) and cultured overnight at 37 ${ }^{\circ} \mathrm{C}$ in a humidified atmosphere of $5 \% \mathrm{CO}_{2}$. Test concentrations $(0.5,5,50,250,500 \mu \mathrm{g} / \mathrm{ml}$ MSG in $\left.\mathrm{dH}_{2} \mathrm{O}\right)$ and $\mathrm{dH}_{2} 0$ solvent control diluted in reduced serum media (1\% serum) $(100 \mu \mathrm{l})$ were added and allowed to incubate for $72 \mathrm{~h}$. Media from each well was harvested and retained at $24 \mathrm{~h}$ intervals and replaced by fresh media containing the appropriate concentration of MSG or vehicle control. Samples were stored at $-20{ }^{\circ} \mathrm{C}$ until immediately before assay of the GLP-1 content at which time the 3 x $200 \mu$ l samples from each well were pooled.

\subsection{Hormone Analysis}


GLP-1 was measured using a Glucagon Like Peptide-1 (GLP-1) (Active) ELISA kit (EGLP35K; in accordance with the manufacturer's instructions (Millipore, Watford, UK). All experiments were performed in triplicate for each experimental point and repeated in three independent experiments. Responses of cells to the test compound were compared with the negative control $\left(\mathrm{dH}_{2} \mathrm{O}, 0.1 \%\right)$.

\subsection{Statistical Analysis}

All values shown are expressed as mean \pm standard error of the mean (SEM) of the three independent exposures for MSG. Data from the cell viability, GLP-1R redistribution assay and GLP-1 ELISA were analysed using Microsoft Excel and GraphPad PRISM 5 software (GraphPad Software Inc, San Diego, CA). A one-way analysis of variance (ANOVA) followed by Dunnett's multiple comparison test was used to determine significant differences between treatments and the corresponding control. A P-value of $<0.05$ was considered as significant $\left(P<0.05^{*}, P<0.01 * *\right.$ and $\left.P<0.001 * * *\right)$.

\section{Results}

\subsection{Cell viability data}

Viability of the pGIP/neo: STC-1 cells was not affected by any concentration of MSG during either the acute or the chronic study, as determined by AlamarBlue ${ }^{\circledR}$ assay $(P>0.05)$ (data not shown). Although not significantly different, there was some evidence of reduced viability at higher concentrations of MSG at $72 \mathrm{~h}$. However as this is a relatively insensitive assay there was sufficient justification for looking at potential cytotoxic markers on HCA.

Similiarly, MTT assays showed no significant change in viability of the U2OS-GLP1R-EGFP cells following $1 \mathrm{~h}$ exposure to $\mathrm{MSG}(0.5,5,50,250$ and $500 \mu \mathrm{g} / \mathrm{ml})$ (data not shown).

\subsection{Effects of MSG on GLP-1 secretion}

\subsubsection{Effects of 3 h exposure of MSG on GLP-1 secretion}

Following $3 \mathrm{~h}$ exposure of pGIP/neo: STC-1 cells to lower MSG concentrations (0.5-250 $\mu \mathrm{g} / \mathrm{ml}$ ) did not significantly affect GLP-1 secretion. However, at $500 \mu \mathrm{g} / \mathrm{ml}$, MSG stimulated 
a significant $9.6 \mathrm{pg} / 10^{6}$ increase in GLP-1 secretion $\left(22.4 \mathrm{pg} / 10^{6}\right.$ cells in $500 \mu \mathrm{g} / \mathrm{ml} \mathrm{MSG}$ vs. $12.8 \mathrm{pg} / 10^{6}$ cells in control; $\left.P<0.001\right)$ (Fig.2).

\subsubsection{Effects of $72 \mathrm{~h}$ exposure of MSG on GLP-1 secretion}

Similarly 72 h exposure of pGIP/neo: STC-1 cells to lower MSG concentrations (0.5-250 $\mu \mathrm{g} / \mathrm{ml}$ ) did not significantly affect GLP-1 secretion. However, at $500 \mu \mathrm{g} / \mathrm{ml}$ MSG there was a significant decrease in GLP-1 secretion by $35.9 \mathrm{pg} / 10^{6}$ cells $\left(45.4 \mathrm{pg} / 10^{6}\right.$ cells in $500 \mu \mathrm{g} / \mathrm{ml}$ MSG vs 81.4 pg $/ 10^{6}$ cells in control $\left.P<0.05\right)$ (Fig.3).

\subsection{Cytotoxicity}

The potential cytotoxicity of either $3 \mathrm{~h}$ or $72 \mathrm{~h}$ exposure to MSG (0.5, 5, 50, 250 and 500 $\mu \mathrm{g} / \mathrm{ml}$ ) on pGIP/neo: STC-1 intestinal cells was assessed by HCA analysis by measuring cell number and nuclear morphology including nuclear intensity, and nuclear area.

Mitochondrial membrane potential dye was used to measure mitochondrial health, specifically mitochondrial membrane potential and mitochondrial mass. For $3 \mathrm{~h}$ MSG exposure no cytotoxicity was observed at any MSG concentrations (data not shown).

However, following $72 \mathrm{~h}$ exposure, $250 \mu \mathrm{g} / \mathrm{ml}$ MSG decreased cell number by $11.8 \%(P<$ $0.05)$, increased nuclear area by $23.9 \%(P<0.001)$ and decreased mitochondrial membrane potential by $13 \%(P<0.05)$. MSG $(500 \mu \mathrm{g} / \mathrm{ml})$ decreased cell number by $26.7 \%(P<0.001)$, increased nuclear area by 29.8\% $(P<0.001)$, increased mitochondrial mass by $16.3 \%(P<$ $0.01)$ and decreased mitochondrial membrane potential by $21.6 \%(P<0.001)$ (Fig. 4 and 5).

\subsection{GLP-1R internalisation assay}

A standard curve was generated using various concentrations of GLP-1 (1-300 nM) to drive receptor internalisation (Fig.6). The EC50 value was calculated as 37 nM GLP-1.

MSG did not cause internalization of the GLP-1R in U2OS-GLP1R-EGFP cells. Furthermore, exposure to MSG (0.5-500 $\mu \mathrm{g} / \mathrm{ml})$ during the period of exposure to GLP-1 did not affect GLP-1-mediated internalisation of the GLP-1R (Figure 7). 


\section{Discussion}

327 Associations between MSG consumption and increased incidence of diabetes and obesity 328 have been reported in both human and animal studies (He et al., 2011; Insawang et al. 2012;

329 Miskowiak et al., 1993). However, a potential mechanism has not yet been identified. This 330 study hypothesised that MSG might interact with the GLP-1 hormone, either through the 331 GLP-1R or by affecting GLP-1 secretion. For an obesogen, GLP-1 is a plausible potential 332 target given its pleiotropic actions on satiety responses, post-prandial insulin and glucagon secretion, gut motility, and gastric acid secretion.The present study investigated whether MSG has a disrupting effect on the secretion of the incretin hormone GLP-1 or its interaction with its receptor. Cytotoxic responses were evaluated in pGIP/neo: STC-1 cells, an EE cell model which secretes GLP-1. EE cells are one of four subtypes of epithelial cells lining the gut (Beucher et al., 2012) and collectively are the largest endocrine system in the body. The cells used in this study (pGIP/neo: STC-1) are a sub-clone of the STC-1 cell line which secretes GLP-1 (Gillespie et al., 2015; Jafri et al., 2016). Recent studies suggest that EE cells are more flexible than previously thought because they alter the profile of hormones made and released in response to nutrient changes in the diet (Habib et al. 2012). As pGIP/neo: STC-1 cells are a pluri-hormonal EE cell line (also secreting cholecystokinin, peptide YY and glucose-dependent insulinotropic polypeptide) (Hand et al., 2012) that imitate some of the other hormonal influences which exist in the intestine in vivo such as having the potential to release other gut hormones.

A previous study on the STC-1 parental cells provides evidence that exposure to MSG can activate the nutrient sensing T1R1/T1R3 (taste receptors) umami receptor. Additionally, MSG exposure to the STC-1 cells induced neurotensin (NT) release, a peptide involved in the regulation of hormone release from the gut (Kendig et al., 2015). However, in the present study the potential of MSG to interfere with GLP-1 interaction with the GLP-1R was examined and under all of the various test conditions there was no evidence of this. It is important to mention that the cell lines used for the present study and the Kendig et al., (2015) study differ,as well as the receptor investigated, therefore accounting for differences in findings.

When studying the effects of MSG on intestinal EE cells, which produce and release GLP-1, 
doubling the amount of hormone that is released. Previously, it has been demonstrated in vivo that an acute bolus of MSG increases plasma GLP-1 in healthy male volunteers (Hosaka et al. 2012). The present data suggest that this could be a consequence of a direct effect of MSG on GLP-1 secretion by EE cells.

Secretion of GLP-1 occurs primarily in response to nutrient ingestion, particularly glucose and fat and to a lesser extent specific amino acids and protein hydrosylates (Elliott et al., 1993, Ramshur et al., 2002). However, it may not solely be the presence of nutrients that stimulates secretion. A biphasic release of GLP-1 into the circulation following a meal has been established (Rask et al., 2001) which would suggest the potential input of neural and endocrine factors. It is believed that GLP-1 secretion may prove even more complex than other gut hormones. In particular, glutamine, a breakdown product of MSG, may be even more effective than glucose or other amino acids as a GLP-1 secretagogue. Glutamine triggers membrane depolarisation and increases intracellular calcium; however asparginine and alanine also increase intracellular calcium without increasing GLP-1 secretion (Reimann et al., 2004). In the presence of diazoxide (a potassium channel activator) and a depolarising concentration of potassium chloride, glutamine still enhanced GLP-1 secretion (Reimann et al., 2004), therefore glutamine-induced GLP-1 secretion may not be exclusively dependent on membrane polarisation. Therefore, the mechanism by which MSG induced an increase in GLP-1 secretion following $3 \mathrm{~h}$ exposure, may have been consequential of the breakdown product of MSG, glutamine. The paracrine actions of somatostatin, secreted from neighbouring D-cells exerts an inhibiting effect on GLP-1 secretion and may prove pivotal in producing a feedback loop for GLP-1 regulation following nutrient ingestion (Hansen et al., 2000; Lahlou et al., 2004). Previous studies using the parental STC-1 cell line have demonstrated that exposure to glutamine elevated the intracellular $\mathrm{Ca}^{2+}$ levels (Miyata et al., 2014). It may be via this mechanism that the GLP-1 secretion is increased following 3 hour exposure to higher concentrations of MSG

MSG is consumed on a daily basis and is present in a wide variety of foods and therefore it was logical to examine the effects of a longer exposure on GLP-1 secretion (72 h) mimicking daily consumption. When pGIP/neo STC-1 cells were exposed to MSG for $72 \mathrm{~h}$,a detrimental effect on GLP-1 secretion leading to a 1.8-fold reduction in the amount of hormone released was observed. A possible explanation for the chronic decrease in GLP-1 secretion is that MSG-induced stimulation of GLP-1 secretion (as observed with $3 \mathrm{~h}$ exposure) leads to a depletion in the capacity of EE cells to secrete GLP-1. However this 
would need to be studied in more detail with further investigations. This observation has potential physiological relevance given that GLP-1 secretion may be blunted/impaired in patients with type 2 diabetes. For example, reduced postprandial concentrations of intact biologically active GLP-1 have been observed in type 2 diabetic patients and it seem likely that that these reductions in GLP-1 secretion result in impaired insulin secretion (Vilsbøll et al., 2001). Therefore our observation that 72 h MSG exposure leads to a decline in GLP-1 secretion suggests that it may be a contributing factor in the pathogenesis of diabetes/obesity.

A novel HCA assay measuring nuclear and mitochondrial parameters was developed to assess the cellular health of EE cells under conditions of both $3 \mathrm{~h}$ and $72 \mathrm{~h}$ MSG exposure. No cytotoxicity was evident when the EE cells were exposed to MSG for $3 \mathrm{~h}$, however, significant toxic effects were observed following $72 \mathrm{~h}$ exposure. Concentration-dependent reductions in cell number and in mitochondrial membrane potential were observed, as were increases in nuclear area and mitochondrial mass.

MSG exposure studies are scarce in the literature. However, several in vivo single-dose studies have shown the potential of MSG to impact negatively upon cells and ultimately lead to cell death. One study investigated the exposure of rat thymocytes to MSG (4 mg/g body weight) and found a dose-dependent decrease in cell survival with cell loss occurring primarily through apoptosis (Pavlovic et. al., 2009). Increased apoptosis can arise from the absence of survival factors and cell-to-cell signalling mechanisms that are present in vivo (Elmore, 2007). The concentration-dependent manner in which MSG induces apoptosis has been noted previously whereby glutamate-induces cell death via apoptosis or necrosis (Ankarcrona et. al., 1995). The results of the present study provide no evidence of $3 \mathrm{~h}$ toxic effects, but again this can be due to a number of other factors including the cell type used, the MSG concentrations employed and the duration of exposure.

In the present study there was a good association between the MSG concentrations that caused decline in GLP-1 secretion and those which caused cytotoxic effects. At the highest MSG concentration tested $(500 \mu \mathrm{g} / \mathrm{ml})$ there was a significant decrease in both cell number and in mitochondrial membrane potential but a significant increase in mitochondrial mass and nuclear area. It is well established that biogenesis of mitochondria can increase mitochondrial mass as a result of increased mitochondrial respiration, and that this usually corresponds with reduced mitochondrial membrane potential (O'Brien and Haskins, 2007). Mitochondria are organelles involved in the regulation of programmed cell death (apoptosis). This often occurs 
when cells are damaged by disease or toxic agents (Norbury and Hickson, 2001). Due to the increase in nuclear area observed in the study, it would appear that some cells underwent necrosis. In the case of necrosis, the cells will swell and consequently cause an increase in nuclear area, as observed in the present study. Although there are distinct differences in the mechanisms of apoptosis and necrosis, there is overlap between the two processes described as the "apoptosis-necrosis continuum" (Zeiss, 2003) and the results of the HCA assays suggest that the highest concentration ( $500 \mu \mathrm{g} / \mathrm{ml}$ ) of MSG is capable of inducing "apoptosisnecrosis continuum” in EE cells during the $72 \mathrm{~h}$ exposure.

The concentrations of MSG used in this study were based on dietary exposure levels, average daily intakes across different populations and at levels higher than these levels to account for underestimations in MSG intake (Collision et al., 2009; He et al., 2011; Nakanishi et al., 2008; Shi et al., 2014). Maximum MSG solubility was achieved at $500 \mathrm{mg} / \mathrm{ml}$, giving a top concentration on the assay plate of $500 \mu \mathrm{g} / \mathrm{ml}$, equivalent to an exposure of $30 \mathrm{~g} / \mathrm{day}$. Although this is much higher than average daily intakes discussed, as outlined in the introduction, restaurants add unknown amounts of MSG to foods, therefore it is difficult to estimate accurate exposure and it is therefore possible certain groups of the population could be exposed to these high levels, where the present study found significant effects. Furthermore, in a society where MSG is not regulated and consumers are increasingly eating out or purchasing take-away foods, it is not unreasonable to suggest that MSG exposure is likely to be on the increase. It is also worth mentioning the potentially greater health risks which Asian populations are being subjected to as a result of their excessive MSG exposure. Large scale epidemiological studies are clearly warranted to provide better estimates of MSG consumption. The setting of maximum levels of MSG content in foods is something which should be given serious consideration. This would have the added benefit of improving the accuracy of consumer exposure for this food additive.

\section{Conclusion}

This is the first study to examine a potential endocrine disrupting effect of MSG, a suspected obesogen, on the interaction with the GLP-1 hormone. This study demonstrates that MSG, has the ability to stimulate GLP-1 secretion from pGIP/neo: STC-1 cells, an EE cell model following $3 \mathrm{~h}$ exposure, but that longer-term exposure leads to impaired GLP-1 secretion and a range of changes indicative of cytotoxicity. The multi-parameter HCA cytotoxicity assay 
utilised here was able to detect subtle changes in cell health and this has great potential for investigating the potential endocrine disrupting effects of other putative obesogens.

\section{Conflict of interest}

There is no conflict of interest.

\section{References}

Ankarcrona, M., Dypbukt, J. M., Bonfoco, E., Zhivotovsky, B., Orrenius, S., and Lipton, S. A. (1995). Glutamate-Induced Neuronal Death: A Succession of Necrosis or Apoptosis Depending on Mitochondrial Function. Neuron, 15, 961-973

Baggio, L. and Drucker, D. (2007). Biology of Incretins: GLP-1 and GIP. Gastroenterology, 132, 2131-2157.

COT(2013). Scoping paper on the obesogen hypothesis (pp. 1-23).Available from: https://cot.food.gov.uk/sites/default/files/cot/tox2013.pdf (Accessed: 12/06/16).

Beucher, E. Gjernes, C. Collin, M. Courtney, A. Meunier, and P. Collombat, (2012).The homeodomain-containing transcription factors Arx and Pax4 control enteroendocrine subtype specification in mice. PLoS One, 7 (5) e36449

Buse J., Nauck M., Forst T., Sheu W., Shenouda S., Heilmann C., et. al., (2013) Exenatide once weeklyversus liraglutide once daily in patients with type 2 diabetes (DURATION-6): a randomised, open-label study. Lancet 381: 117-124

Clough, R., Ararich, P., and Sladek, C.(1986). Monosodium glutamate neurotoxicity: A sexspecific impairment of blood pressure but not vasopressin in developing rats. Brain Research Bulletin, 17(1), 51-58.

Collison, K. S., Maqbool, Z., Saleh, S. M., Inglis, A., Makhoul, N. J., Bakheet, R., and AlMohanna, F. A. (2009). Effect of dietary monosodium glutamate on trans fat-induced nonalcoholic fatty liver disease. Journal of Lipid Research, 50, 1521-1537.

D’Alessio, D. a, Vogel, R., Prigeon, R., Laschansky, E., Koerker, D., Eng, J., and Ensinck, J. W. (1996). Elimination of the action of glucagon-like peptide 1 causes an impairment of 
480

481

482

483

484

485

486

487

488

489

490

491

492

493

494

495

496

497

498

499

500

501

502

503

504

505

506

507

glucose tolerance after nutrient ingestion by healthy baboons. The Journal of Clinical Investigation, 97(1), 133-8.

Drucker, D. J. (2006). The biology of incretin hormones. Cell Metabolism, 3(3), 153-65.

Edwards, C., Todd, J.and Mahmoudi, M. (1999). Glucagon-like peptide 1 has a physiological role in the control of postprandial glucose in humans: studies with the antagonist exendin 939. Diabetes, 48, 86-93.

Elliott, R. M., Morgan, L. M., Tredger, J. A., Deacon, S., Wright, J., and Marks, V. (1993). Glucagon-like peptide-1(7-36)amide and glucose-dependent insulinotropic polypeptide secretion in response to nutrient ingestion in man - acute postprandial and 24- $\mathrm{H}$ secretion patterns. Journal of Endocrinology, 138, 159-166.

Elmore, S. (2007). Apoptosis: a review of programmed cell death. Toxocologic Pathology, 35(4), 495-516

FDA. (2012). Questions and Answers on Monosodium glutamate (MSG). Retrieved January 06, 2015 , from http://www.fda.gov/Food/IngredientsPackagingLabeling/FoodAdditivesIngredients/ucm3287 28.htm

Gillespie, A. L., Calderwood, D., Hobson, L., and Green, B. D. (2015). Whey proteins have beneficial effects on intestinal enteroendocrine cells stimulating cell growth and increasing the production and secretion of incretin hormones. Food Chemistry, 189, 120-128

Green, B. D., Irwin, N., Gault, V. a., Bailey, C. J., O’Harte, F. P. M., and Flatt, P. R. (2005). Chronic treatment with exendin(9-39)amide indicates a minor role for endogenous glucagonlike peptide-1 in metabolic abnormalities of obesity-related diabetes in ob/ob mice. Journal of Endocrinology, 185, 307-317

Habib, AM, Richards, P, Cairns, LS, Rodger, GJ, Bannon, CA and Parker, HE. (2012). Overlap of endocrine hormone expression in the mouse intestine revealed by transcriptional profiling and flow cytometry. Endocrinology. 153 (7), p3054-3065.Hand, K. V, Giblin, L., and Green, B. D. (2012). Hormone profiling in a novel enteroendocrine cell line pGIP/neo: STC-1. Metabolism: Clinical and Experimental, 61(12), 1683-6. 
508

509

510

511

512

513

514

515

516

517

518

519

520

521

522

523

524

525

526

527

528

529

530

531

532

533 534

Hand, K. V, Giblin, L., and Green, B. D. (2012). Hormone profiling in a novel enteroendocrine cell line pGIP/neo: STC-1. Metabolism: Clinical and Experimental, 61(12), 1683-6.

Hansen, L., Hartmann, B., Bisgaard, T., Mineo, H., Jorgensen, P. N., and Holst, J. J. (2000). Somatostatin restrains the secretion of glucagon-like peptide- 1 and-2 from isolated perfused porcine ileum. American Journal of Physiology-Endocrinology and Metabolism, 278, E1010E1018

He K, Zhao L, Daviglus ML, Dyer AR, Van Horn L, Garside D, Zhu L, Guo D, Wu Y, Zhou B, Stamler J (2008) Association of monosodium glutamate intake with overweight in Chinese adults: the INTERMAP study. Obesity 16:1875-1880

He, K., Du, S., Xun, P., Sharma, S., Wang, H., Zhai, F., and Popkin, B. (2011). Consumption of monosodium glutamate in relation to incidence of overweight in Chinese adults : China Health and Nutrition Survey ( CHNS ) American Journal of Clinical Nutrition, 1 - 3, 1-3.

Hirata, E., Andrade, I. S., Vaskevicius, P., and Dolnikoff, M. S. (1997). Monosodium glutamate (MSG)-obese rats develop glucose intolerance and insulin resistance to peripheral glucose uptake. Brazilian Journal of Medical and Biological Research, 30(5), 671-4.

Holtcamp, W. (2012). Obesogens: An environmental link to obesity. Environmental Health Perspectives, 120(2), a62-a68.

Hosaka, H, Kusano, M and Zai, H. (2012). Monosodium glutamate stimulates secretion of glucagon-like peptide-1 and reduces postprandial glucose after a lipid-containing meal. Alimentary pharmacology and Therapeutics. 36 (1), p95-903.

Husarova, V., and Ostatnikova, D. (2013). Monosodium Glutamate Toxic Effects and Their Implications for Human Intake: A Review. JMED Research, 2013, 1-12.

Insawang, T., Selmi, C., Cha'on, U., Pethlert, S., Yongvanit, P., Areejitranusorn, P., and Hammock, B. D. (2012). Monosodium glutamate (MSG) intake is associated with the prevalence of metabolic syndrome in a rural Thai population. Nutrition \& Metabolism, 9(1), 50. 
535

536

537

538

539

540

541

542

543

544

545

546

547

548

549

550

551

552

553

554

555

556

557

558

559

560

Iwase, M., Yamamoto, M., Iino, K., Ichikawa, K., Shinohara, N., Yoshinari, M., and Fujishima, M. (1998). Obesity induced by neonatal monosodium glutamate treatment in spontaneously hypertensive rats: an animal model of multiple risk factors. Hypertension Research : Official Journal of the Japanese Society of Hypertension, 21(1), 1-6.

Jafri, L., Saleem, S., Calderwood, D., Gillespie, A., Mirza, B., and Green, B. D. (2016).

Naturally-occurring TGR5 agonists modulating glucagon-like peptide-1 biosynthesis and secretion. Peptides, 78, 51-58.

Kendig, D., Bala, V., Murthy, K. and Grider, J., (2015) Neurotensin Partially Mediates the Monosodium Glutamate (MSG)-Induced Peristaltic Reflex. The FASEB Journal, 29(1 Supplement), pp.850-1.

Kolligs, F., Fehmann, H., Goke, R., and Goke, B. (2002). Reduction of the incretin effect in rats by the glucagon-like peptide 1 receptor antagonist exendin (9-39) amide. Diabetes, 44, $16-19$.

Kuna, R. S., Girada, S. B., Asalla, S., Vallentyne, J., Maddika, S., Patterson, J. T and Mitra, P. (2013). Glucagon-like peptide-1 receptor-mediated endosomal cAMP generation promotes glucose-stimulated insulin secretion in pancreatic ${ }^{N}\llcorner$-cells. American Journal of Physiology Endocrinology and Metabolism, 305 (2), E161-E170.

Lahlou, H., Guillermet, J., Hortala, M., Vernejoul, F., Pyronnet, S., Bousquet, C., and Susini, C. (2004). Molecular signaling of somatostatin receptors. Gastroenteropancreatic Neuroendocrine Tumor Disease: Molecular and Cell Biological Aspects, 1014, 121-131. creatic Neuroendocrine Tumor Disease: Molecular and Cell Biological Aspects, 1014, 121131.

Macdonald, P. E., El-kholy, W., Riedel, M. J., Salapatek, A. M. F., Light, P. E., and Wheeler, M. B. (2002). The Multiple Actions of GLP-1 on the Process of Glucose-Stimulated Insulin Secretion, Diabetes 51 S434-S442 
561

562

563

564

565

566

567

568

569

570

571

572

573

574

575

576

577

578

579

580

581

582

583

584

585

586

Mercola (2009) MSG: Is This Silent Killer Lurking in Your Kitchen Cabinets. Available from: http://articles.mercola.com/sites/articles/archive/2009/04/21/msg-is-this-silent-killerlurking-in-your-kitchen-cabinets.aspx. Accessed: 12/06/16

Miskowiak B., Limanowski A., and Partyka M. (1993): Effect of perinatal administration of monosodium glutamate (MSG) on the reproductive system of the male rat. Endokrynologia Polska 44, 497-505

Miyata, M., Kurogi, M., Oda, M. and Saitoh, O., (2014) Effect of five taste ligands on the release of CCK from an enteroendocrine cell line, STC-1. Biomedical Research, 35(2), pp.171-176.Newbold, R. R., Padilla-banks, E., Snyder, R. J., Phillips, T. M., and Jefferson, W. N. (2007). Developmental exposure to endocrine disruptors and the obesity epidemic. National Institute of Health, 23(3), 290-296.

Kuna, R. S., Girada, S. B., Asalla, S., Vallentyne, J., Maddika, S., Patterson, J. T., and Mitra, P. (2013). Glucagon-like peptide-1 receptor-mediated endosomal cAMP generation promotes glucose-stimulated insulin secretion in pancreatic ${ }^{N}\llcorner$-cells. American Journal of Physiology Endocrinology and Metabolism, 305(2), E161-E170.

Noerklit, S., Wismann, P., Rye, C., Kulahin, N., Iversen, H., Arevad, K.,and Waldhoer, M. (2014). Molecular and Cellular Endocrinology Real-time trafficking and signaling of the glucagon-like peptide-1 receptor. Molecular and Cellular Endocrinology, 382 (2), 938-949.

Norbury, C.J., and Hickson, I.D., (2001). Cellular responses to DNA damage. Annual Reviews in Pharmacology and Toxicology. 41, 367-401

O'Brien, P., (2008). High content analysis of sub lethal cytotoxicity in human HepG2 hepatocytes for assessing potential and mechanism for chemical and drug induced human toxicity. High Content Screening (Science, Techniques, and Applications) (Haney, S.A). Wiley, NJ, pp. 293-315 
587 O'Brien, P., and Haskins, J.R., (2007). In vitro cytotoxicity assessment. In: Taylor, D.L., 588 Haskins, J.R., Giuliano, K.A. (Eds.), High Content Screening (Methods in Molecular 589 Biology). Humana Press, NJ, USA, pp. 415-425.

590 Olney, J. (1969). Brain lesions, obesity, and other disturbances in mice treated with 591 monosodium glutamate. Science., 164(880), 719-721.

592 Pavlovic, V, Pavlovic, D and Kocic, A. (2009). Ascorbic acid modulates monosodium 593 glutamate induced cytotoxicity in rat thymus. Bratislavske Lekarske Listy. 110 (4), p205-209.

594 Ramshur, E. B., Rull, T. R., and Wice, B. M. (2002). Novel insulin/GIP co-producing cell 595 lines provide unexpected insights into gut K-cell function in vivo. Journal of Cellular 596 Physiology, 192, 339-350.

597 Rask, E., Olsson, T., Soderberg, S., Johnson, O., Seckl, J., Holst, J. J., and Ahren, B. (2001). 598 Impaired incretin response after a mixed meal is associated with insulin resistance in 599 nondiabetic men. Diabetes Care, 24, 1640-1645.

600 Reimann, F., Williams, L., Xavier, G. D., Rutter, G. A., and Gribble, F. M. (2004). 601 Glutamine potently stimulates glucagon-like peptide-1 secretion from GLUTag cells. 602 Diabetologia, 47, 1592-1601. Scrocchi, L., Brown, T., and MacLusky, N. (1996). Glucose intolerance but normal satiety in 604 mice with a null mutation in the glucagon-like peptide receptor gene. Nature Medicine, 2, 605 $1254-1258$.

606 Sharpe, R. M., and Drake, A. J. (2013). Obesogens and obesity--an alternative view? Obesity 607 (Silver Spring, Md.), 21(6), 1081-3.

608 Shaw, J. E., Sicree, R. a., and Zimmet, P. Z. (2010). Global estimates of the prevalence of 609 diabetes for 2010 and 2030. Diabetes Research and Clinical Practice, 87, 4-14.

610 Svidnicki PV, de Carvalho Leite N, Venturelli AC, Camargo RL, Vicari MR, de Almeida 611 MC, Artoni RF, Nogaroto V, Grassiolli S. (2013) Swim training restores glucagon-like 612 peptide-1 insulinotropic action in pancreatic islets from monosodium glutamate-obese rats. 613 Acta Physiologica 209(1):34-44. 
614 Vilsbøll, T., Krarup, T., Deacon, C. F., Madsbad, S., \& Holst, J. J. (2001). Reduced 615 Postprandial Concentrations of Intact Biologically Active Glucagon-Like Peptide 1 in Type 2 616 Diabetic Patients. Diabetes, 50, 609-613.

617 Zeiss, C.J., 2003. The apoptosis-necrosis continuum: insights from genetically altered mice. 618 Veterinary Pathology 40 (5), 481-495.

\section{Figure legends}

620 Fig. 1: Images illustrating the GLP-1R redistribution. A) DMSO control and B) treated with 621 agonist GLP-1 (300 nM). Typical HCA micrographs are shown with nuclei (blue) and GLP$6221 R$ fluorescence (green) X 20 objective magnification. $1 B$ shows GLP-1R-EGFP 623 internalisation that is detected by the image analysis algorithm.

624 Fig. 2. GLP-1 secretory responses of pGIP/neo: STC-1 cells during acute (3 h) exposure to 625 MSG. Graph shows GLP-1 secretion from $p G I P / n e o: ~ S T C-1$ cells (mean $\pm S E M, n=3$ ) 626 following $3 \mathrm{~h}$ incubation with $0.5-500 \mu \mathrm{g} / \mathrm{ml} M S G$.

627 Fig. 3. GLP-1 secretory responses of pGIP/neo: STC-1 cells during chronic (72 h) exposure 628 to MSG. Graph shows GLP-1 secretion from $p G I P / n e o: ~ S T C-1$ cells (mean $\pm S E M, n=3$ ) following $72 \mathrm{~h}$ incubation with $0.5-500 \mu \mathrm{g} / \mathrm{ml} M S G . P<0.05\left(^{*}\right)$ represent significance.

Fig. 4: Cytotoxic effects on pGIP/neo STC-1 cells of MSG 0.5- $500 \mu \mathrm{g} / \mathrm{ml}$ following $72 \mathrm{~h}$ exposure. A number of endpoints were measured including a) Cell number, b) Nuclear area, c) Nuclear Intensity, d) Mitochondrial mass and e) Mitochondrial membrane potential. Data are expressed as a percentage of solvent control $\left(\mathrm{dH}_{2} \mathrm{O}\right)$ for each parameter. Data are mean \pm SEM, $n=3 ; P<0.05(*)<0.01(* *)<0.001(* * *)$ versus appropriate control.

Fig. 5: HCA images for a) solvent control and b) MSG-treated (500 $\mu \mathrm{g} / \mathrm{ml}$ ) following $72 \mathrm{~h}$ exposure of pGIP/neo: STC-1 cells. Each image was acquired at $\times 10$ objective magnification using Hoechst dye (blue; nuclear staining) and mitochondrial potential dye (red; mitochondrial staining).

639

Fig. 6: GLP-1 standard curve (1-300 $\mathrm{nM}$ ) relative to the DMSO negative control in the 640 U2OS-GLP1R-ERFP cell line. Data are mean+sem, $n=3$. GLP-1R internalisation was normalised to vehicle control (0.2\% DMSO) and 300 nM GLP-1 (100\%). The EC50 value was calculated at $37 \mathrm{nM}$. 
643 Figure 7: Images illustrating the GLP-1R redistribution assay following MSG exposure. A)

644 DMSO control, B) treated with MSG $500 \mu \mathrm{g} / \mathrm{ml}$ C) Positive control (GLP-1 $150 \mathrm{nM}$ ) and D)

645 MSG $500 \mu \mathrm{g} / \mathrm{ml}$ and GLP-1 150 nM. Typical HCA micrographs are shown with nuclei (blue)

646 and GLP-1R fluorescence (green) X 20 objective magnification. 